\title{
Secondary vascular alterations in nutcracker phenomenon and its variants on multidetector CT
}

\section{Nutcracker fenomeni ve varyantlarında çok kesitli BT'de görülen sekonder vasküler değişiklikler}

\section{Bilge Öztoprak}

\author{
Cumhuriyet University School of Medicine, Department of Radiology, Sivas, Turkey \\ Corresponding author: Bilge Öztoprak, Cumhuriyet University School of Medicine, Department of Radiology, Sivas, \\ Turkey \\ E-mail: bilgeoztoprak@gmail.com \\ Received/Accepted: November 17, 2016 / November 23, 2016
}

Conflict of interest: There is not a conflict of interest.

\begin{abstract}
SUMMARY
Objectives: Nutcracker phenomenon is caused by the compression of left renal vein between the superior mesenteric artery and the aorta. There are also variants namely the 'posterior nutcracker phenomenon' where the posteriorly located retroaortic or circumaortic left renal vein is compressed between the aorta and the vertebral body. The aim of this study is to define the vascular alterations in veins other than the left renal vein secondary to anterior and posterior nutcracker phenomena and emphasize their contribution to the diagnosis.

Method: A total of 258 patients were enrolled in the study. Computed tomography images of 57 patients with nutcracker phenomenon were retrospectively investigated for the presence of secondary vascular alterations. In addition, images of 169 patients with a retroaortic and 32 patients with a circumaortic left renal vein variation were searched for the presence of a posterior nutcracker phenomenon and associated secondary vascular findings.
\end{abstract}

Results: Dilatation of left gonadal (n: 15, 26\%), left lumbar or ascending lumbar (n: 9, 16\%), hemiazygos/accessory hemiazygos (n: 4, 7\%), left suprarenal (n: 4, 7\%), and inferior phrenic (n:2, $4 \%)$ veins were seen in anterior nutcracker phenomenon. Pelvic varices/varicoceles and pseudothrombosis in the left renal vein were present in 7(12\%) and 4 ( 7\%) patients, respectively. $14 \%$ of 169 patients with a retroaortic left renal vein and $16 \%$ of 32 patients with circumaortic left renal vein showed a posterior NC phenomenon and associated vascular alterations.

Conclusions: Awareness of the secondary vascular findings in nutcracker phenomenon may aid in the diagnosis and guide management.

Keywords: Nutcracker phenomenon, posterior nutcracker phenomenon, computed tomography, computed tomography angiography 
ÖZET

Amaç: Nutckracker fenomeni sol renal venin süperior mezenterik arter ile aorta arasında sıkışması sonucu oluşur. 'Posterior nutcracker fenomeni' olarak adlandırılan ve sirkumaortik veya retroaortik sol renal venin aorta ve vertebra korpusu arasında sıkışması sonucu oluşan varyantı da mevcuttur. $\mathrm{Bu}$ çalışmanın amacı anterior ve posterior nutcracker phenomeninde sol renal ven dışındaki damarlarda oluşan sekonder değişiklikleri ortaya koymak ve tanıya katkısına vurgu yapmaktır. Yöntem: Çalışmaya dahil edilen 258 hastanın bilgisayarlı tomografi görüntüleri retrospektif olarak incelendi. Nutcracker fenomeni olan 57 hastanın görüntüleri sekonder vasküler patolojiler yönünden, ayrıca retroaortik sol renal ven vayasyonu olan 169 ve sirkumaortik sol renal ven varyasyonu bulunan 32 hastanın görüntüleri posterior nutcracker fenomeni ve sekonder vasküler bulgu varlığ yönünden araştırıldı.

Bulgular: Nutcracker fenomeni olan hastalarda sol gonadal (n: 15, 26\%), sol lomber veya asendan lomber (n: 9, 16\%), hemiazigos/aksesuar hemiazigos (n: 4, 7\%), sol suprarenal (n: 4, 7\%), ve inferior frenik (n:2, 4\%) venlerde dilatasyon saptandı. Pelvik varisler/varicoseller ve sol renal vende psödothromboz sirasıyla 7(12\%) ve 4 ( 7\%) hastada mevcuttu. Retroaortik sol renal veni olan 169 hastanın \%14'ünde, sirkumaortik sol renal veni olan 32 hastanın \% 16'sında posterior nutcracker fenomeni ve ilişkili vasküler değiş̧iklikler görüldü.

Sonuç: Nutcracker fenomeninde oluşan sekonder vasküler bulguların bilinmesi tanıya yardımcı olabileceği gibi hastanın tedavisinde de yol göstericidir.

Anahtar Sözcükler: Nutcracker fenomeni, posterior nutcracker fenomeni, bilgisayarlı tomografi, bilgisayarlı tomografi anjiografi

\section{INTRODUCTION}

Nutcracker phenomenon is a vascular entrapment syndrome where the left renal vein (LRV) is compressed between the superior mesenteric artery and the aorta ${ }^{1}$. It is also called as the 'mesoaortic compression of the LRV' or 'renal vein entrapment syndrome ${ }^{2,3}$. In the presence of symptoms, such as microscopic or macroscopic hematuria, orthostatic proteinuria or left flank pain, this phenomenon is called a 'syndrome' ${ }^{4}$.

In cases of retroaortic LRV variation, where the LRV courses posterior to the aorta, and circumaortic LRV variation which is characterized by the presence of two branches of LRV anterior and posterior to the aorta, 'posterior nutcracker phenomenon' may occur if the posteriorly located LRV is compressed between the aorta and the vertebral body. Circumaortic LRV is a relatively common anatomic variation which is reported to be due to a lack of regression of the dorsal one of the paired embryonic renal veins ${ }^{5}$. On the other hand, retroaortic left renal vein is thought to be caused by the persistence of dorsal embryonic vein while the ventral branch is regressed.
Nutcracker phenomenon is usually seen in the second and third decades of life and is slightly more frequent in women. It is becoming more commonly encountered with the increased use of multidetector computerized tomography (CT) and computerized tomography angiography (CTA). Diagnosis is often coincidental on CT since most of the patients are asymptomatic or because current complaints are due to or confused with other more common pathologies.

Although the radiologic diagnosis of nutcracker phenomenon can be made via ultrasonography, Doppler ultrasonography, magnetic resonance imaging, and angiography, multidetector CT is currently the method of choice, since it is reliable, rapid and noninvasive ${ }^{6}$. However, in the absence of clinical information suspective of nutcracker phenomenon, it may be overlooked on routine $\mathrm{CT}$ examinations.

Radiologic diagnosis is based on the presence of following findings on CT: Compression of LRV between the superior mesenteric artery and the aorta, decreased aortomesenteric distance $(<10 \mathrm{~mm})$, decreased aortomesenteric angle $\left(<41^{\circ}\right)$, increased ratio of proximal to distal renal vein diameter $(>4.9)$, beaking of the LRV at the stenotic 
segment, presence of retroperitoneal varices [7]. The radiologist should also know the anatomic variations of LRV and secondary vascular findings occurring in the vessels other than the LRV in nutcracker phenomenon in order to reach the correct diagnosis and guide patient management.

The aim of this study is to investigate the vascular alterations secondary to nutcracker phenomenon, as well as the association of posterior nutcracker phenomenon with LRV variants.

\section{MATERIAL AND METHODS}

Institutional ethical approval was obtained (No:2016-05/11, decided on 27 May 2016) and 258 patients were enrolled in this study. Multidetector CT and CTA images of 57 patients with nutcracker phenomenon were retrospectively investigated from August 2013 through May 2016 for the presence of diagnostic vascular appearances and secondary vascular changes. In addition, 201 patients with a retroaortic or circumaortic left renal vein were searched for the existence of a posterior NC phenomenon and accompanying secondary vascular pathologies.

The CT images were obtained using a $64 \times 2$ multidetector computerized tomography device (Aquilion CX, Toshiba, Tokyo, Japan) after intravenous administration of a $1 \mathrm{~mL} / \mathrm{kg}$ iodinated contrast material. The patients who had unenhanced CT examinations or CT images with motion or metal artifacts which enable optimum image interpretation were excluded from the study. Data were analyzed using the version 22.0 of SPSS program. The level of statistical significance was set at 0.05 .

\section{RESULTS}

The ages of the patients ranged between

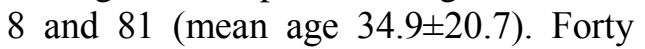
eight percent of patients (n:123) were male and $52 \%$ of patients (n:135) were female. In patients with an anterior nutcracker phenomenon, dilatation of gonadal (n: 15, 26\%), left lumbar or ascending lumbar (n:9, 16\%), hemiazygos/accessory hemiazygos (n: 4, $7 \%$ ), left suprarenal (n: 4, 7\%), and inferior phrenic (n:2, 4\%) veins were depicted (Figs. 1, 2 and 3). Pelvic varices/varicoceles were present in 7 (12\%) patients. There was a pseudothrombosis appearance in the left renal vein in 4 (7\%) patients (Fig. 4). The incidence of having a secondary vascular finding was significantly lower in pediatric age group $(\mathrm{p}<0.05)$ and only one of the 16 pediatric patients showed a dilated left lumbar vein. 


\section{CMJ Original Research December 2016, Volume: 38, Number: 4}

Cumhuriyet Medical Journal
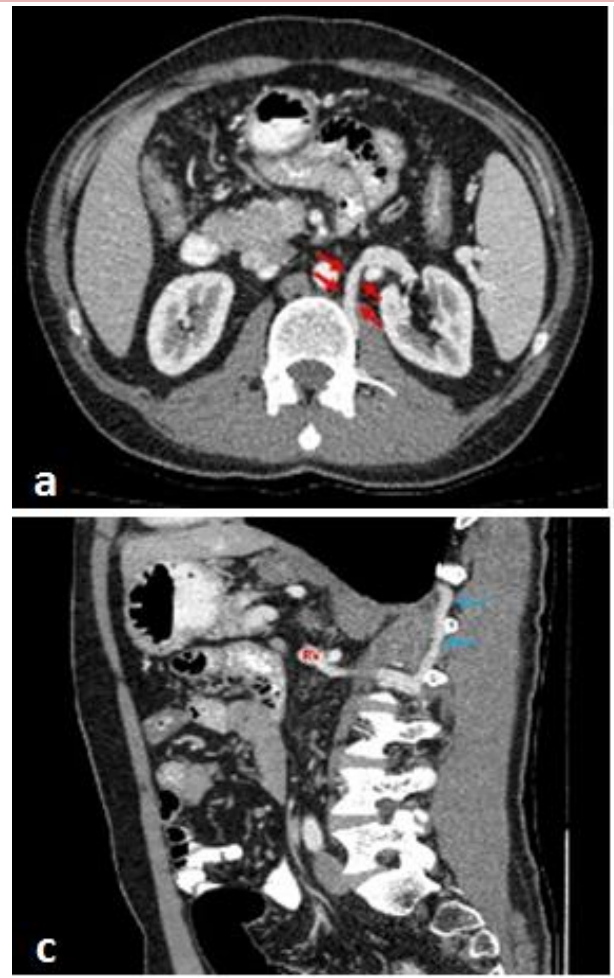

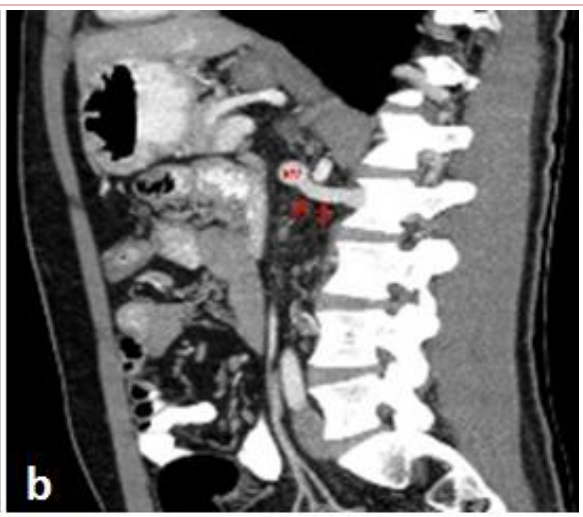

Figure 1. a and b show a dilated left lumbar (red arrows) vein on axial and sagittal reformatted images, respectively. c. A more lateral sagittal reformatted image reveals the dilated ascending lumbar vein (blue arrows, RV:renal vein)
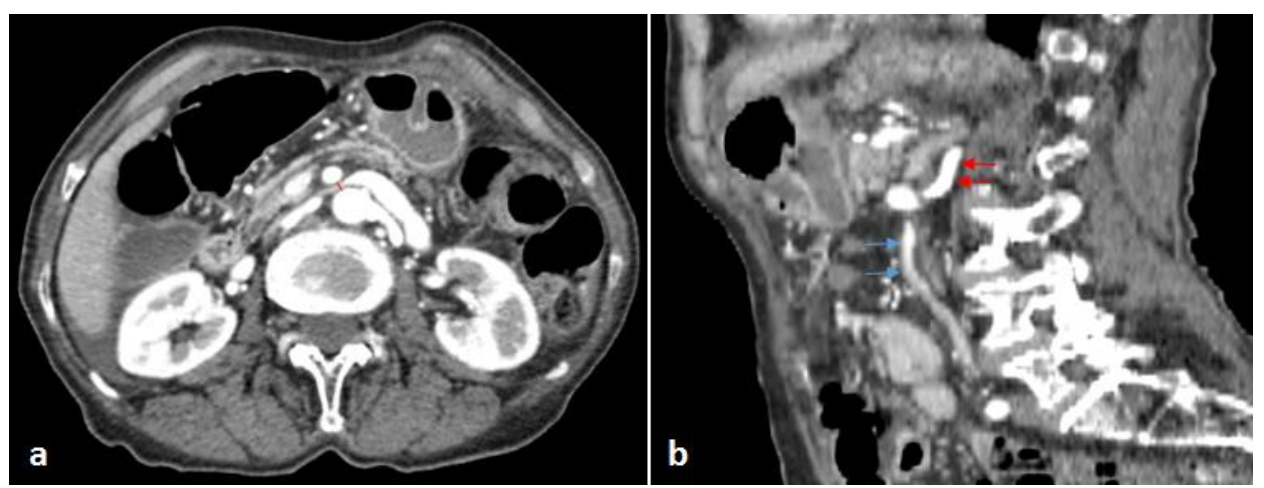

Figure 2.a. Compression of the LRV between superior mesenteric artery and the aorta characterized by the decreased aortomesenteric distance (red line) is seen on the axial image. b. Sagittal reformatted image shows dilated left gonadal vein (blue arrows) and left inferior phrenic vein (red arrows). 


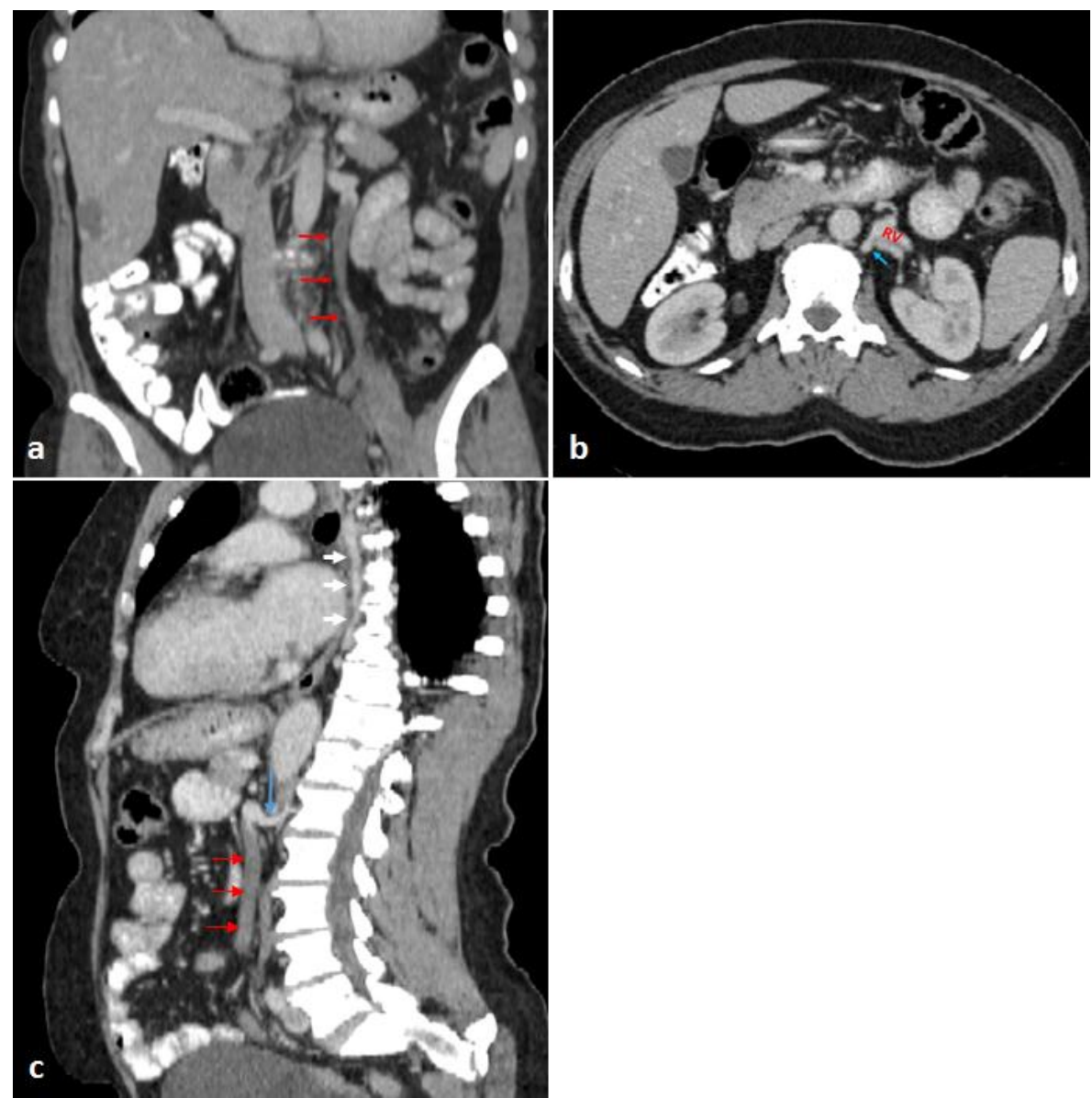

Figure 3.a. A markedly dilated left ovarian vein (red arrows), which is almost as large as the LRV, is seen on the coronal reformatted image. b. Axial image of the same patient shows dilated left lumbar vein with the blue arrow. c. Dilatation of ovarian ( red arrows), lumbar (blue arrow) and accessory hemiazygos (white arrows) veins are seen on sagittal reformatted image (RV: renal vein). 

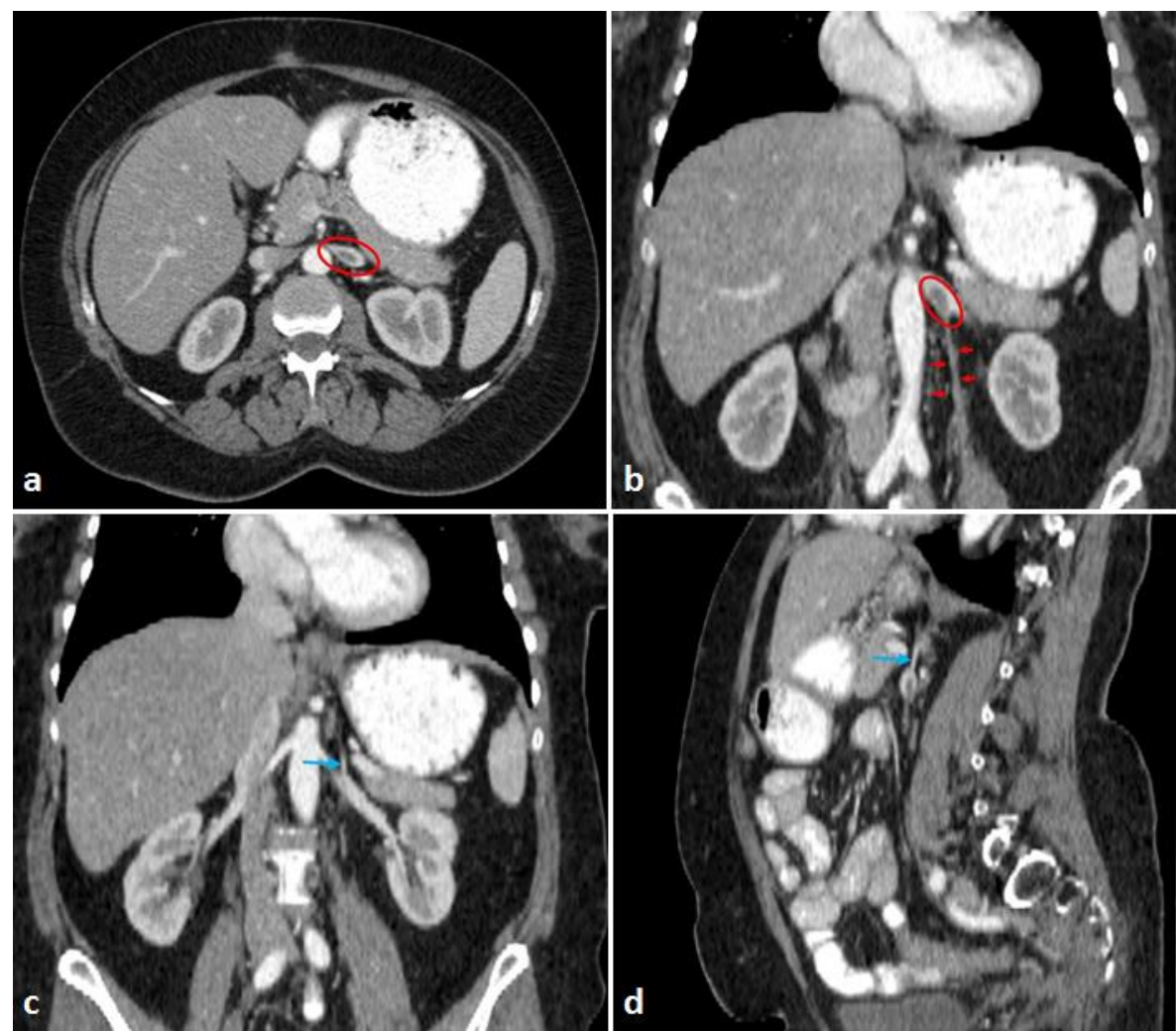

Figure 4. A thrombus-like hypodensity is seen in the left renal vein on the axial image (a). Coronal reformatted image shows that the pseudothrombus appearance is caused by the unenhanced blood coming from the left ovarian vein (b). $\mathbf{c}$ and $\mathbf{d}$ show a small but actually dilated left suprarenal vein draining into the LRV on coronal and sagittal views, respectively, which is normally hard to distinguish on CT.

Regarding the posterior nutcracker phenomenon, 24 (14\%) patients had a posterior nutcracker phenomenon among 169 patients with a retroaortic left renal vein and $5(16 \%)$ of 32 patients with a circumaortic left renal vein showed a posterior nutcracker phenomenon. Among patients with a posterior nutcracker phenomenon, dilatation of left gonadal vein (n:4, $14 \%)$, lumbar /ascending lumbar vein (n: 4, 14\%), inferior phrenic vein $(\mathrm{n}: 1,3 \%)$, and suprarenal vein (n:1,3\%) were noted as a secondary vascular involvement (Figs. 5 and 6). 

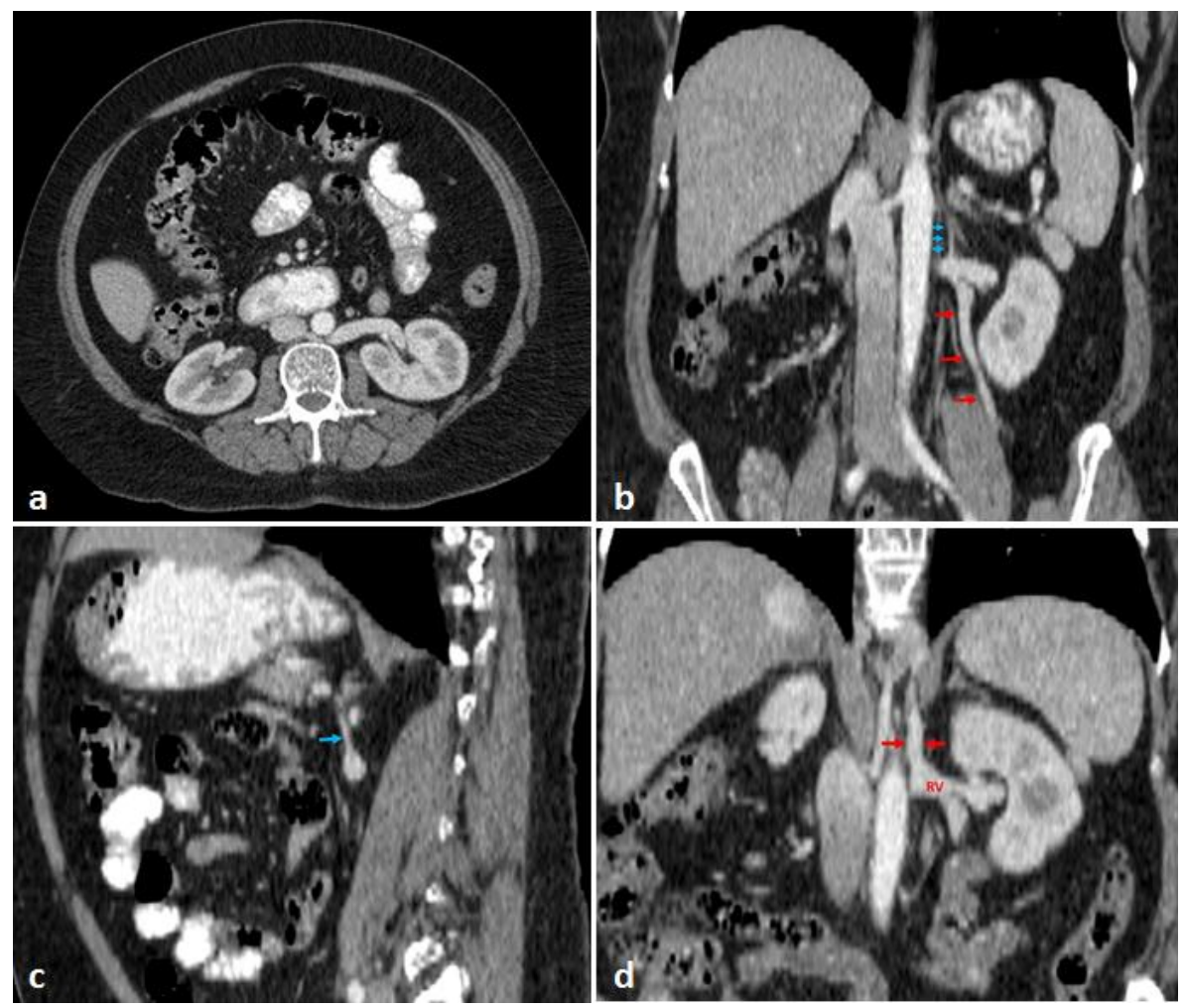

Figure 5.a. Posterior nutcracker phenomenon caused by the compression of LRV between the aorta and the vertebral body. b. Coronal reformatted image shows dilated left ovarian vein (red arrows). Blue arrows in $\mathbf{b}$ and $\mathbf{c}$ show dilated left suprarenal vein on coronal and sagittal planes, respectively. d. Coronal reformatted image of the same patient reveals dilated hemiazygos vein (red arrow) draining into the LRV (RV: renal vein).

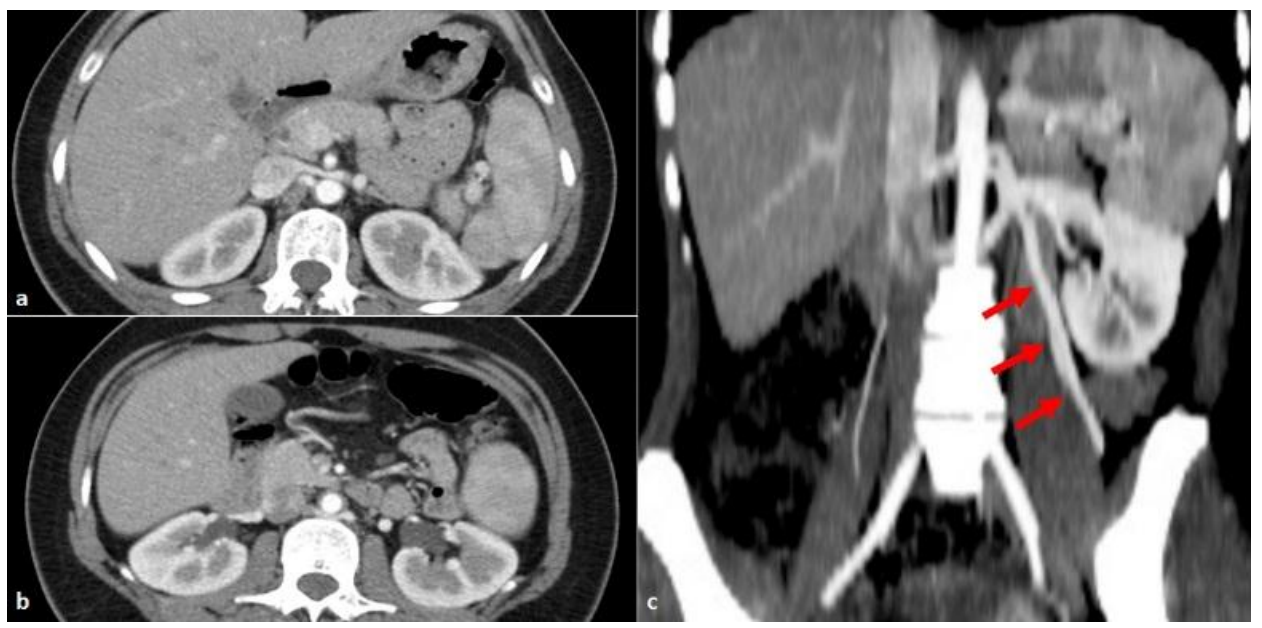

Figure 6. Both anterior and posterior nutcracker phenomena in a patient with circumaortic LRV ( $a$ and $b$ ) and dilated left ovarian vein on maximum intensity projection (MIP) image (c).

\section{DISCUSSION}

Nutcracker phenomenon is a well-known abdominal vascular pathology and its incidence is reported to be underestimated $^{8,9}$. However, its secondary vascular findings and variants are not emphasized in the literature, which may ease the diagnosis by 
directing the attention of the radiologist to the LRV. Any dilatation in the main tributaries of the LRV, namely the left gonadal, suprarenal, inferior phrenic, ureteral, capsular, lumbar, ascending lumbar, vertebral plexus and hemiazygos veins (and sometimes the accessory hemiazygos vein if it is in continuity with the hemiazygos vein) should raise the suspicion of a nutcracker phenomenon. It is noteworthy to say that this phenomenon may be suspected even when interpreting the pulmonary CT images if there is an abnormally enlarged hemiazygos vein or accessory hemiazygos vein.

This study included a quite higher number of patients with retroaortic LRV compared to the number of patients with a circumaortic LRV, although the latter is a more common variation ${ }^{10,11}$. This may be attributable to the possibility of overlooked second LRV which is more inferiorly located and tends to be smaller in diameter. This per se may indicate that posterior nutcracker phenomenon is more common than it is thought to be.

An interesting result of this study is that vascular alterations in veins other than LRV are rare in the pediatric age group. This may be explained by the plastic capacity of the tissues in the young. The LRV may be more elastic in pediatric population compared to adults and compensate the increased pressure by some adaptation mechanisms. However, this issue remains to be investigated.

In both anterior and posterior nutcracker phenomena, the left gonadal veins seem to be the most commonly affected veins from the left renal vein hypertension, followed by the left lumbar/ascending lumbar veins. Sometimes the dilatation of LRV is not obvious because the increased pressure in the LRV is compensated by the enlargement of the veins draining into the LRV, as was seen in some of our patients. In addition, since the LRV is a relatively large vessel and veins are highly variable in terms of diameter, an increase in the diameter of LRV may be imperceptible visually and nutcracker phenomenon may not be noticed. Being aware of the dilated tributaries of LRV may help diagnose the phenomenon.

It must be kept in mind that the unenhanced blood coming from the left gonadal veins may produce a thrombuslike hipodense appearance in the LRV, which was present in $7 \%$ of our patients with nutcracker phenomenon, and it may mimic a malignant thrombus in oncologic patients.

Persistent orthostatic proteinuria, severe hematuria, significant pain, which may be due to the irritation of the left lumbar nerve plexus, and renal functional impairment may necessitate surgical or endovascular intervention in nutcracker syndrome $^{12}$. In cases of left testicular pain in males or pelvic congestion symptoms in females, a careful look at the LRV is crucial to select patients who may benefit from surgical intervention. It is also important in the presurgical evaluation of the transplant donors.

The main limitation of this study is its retrospective design. Many cases may have been unreported since it is not uncommon that the radiologist is mainly focused on other pathologies and overlook the nutcracker phenomenon. Thus, the results of this study do not reflect the true incidence of the phenomenon, which is beyond the main goal of the study. The study cohort is constituted of people who underwent CT and CTA examination for any reason, irrespective of the symptoms. Neither the primary, nor the secondary vascular findings on CT were correlated with the clinical presentation of the patients. The population is too small to make a credible speculation about the differences between anterior and posterior nutcracker phenomena in terms of secondary vascular involvement. A prospective study carried out in larger populations will absolutely be more reliable to define the incidence, extend and preference of secondary vascular involvement and their relationship to clinical symptoms and severeness.

In conclusion, secondary vascular alterations are common in nutcracker phenomenon in adults and may be the first recognized findings on CT. 
Awareness and recognition of secondary vascular alterations in nutcracker phenomenon are important, since they may be the source of the symptoms themselves, as in the cases of pelvic congestion syndrome, and may guide therapeutic attempts.

\section{REFERENCES}

1. Ahmed K, Sampath R, Khan MS. Current trends in the diagnosis and management of renal nutcracker syndrome: a review. Eur J Vasc Endovasc Surg 2006; 31: 410-16.

2. Rudloff U, Holmes RJ, Prem JT, Faust GR, Moldwin R, Siegel D. Mesoaortic compression of the left renal vein (nutcracker syndrome): case reports and review of the literature. Ann Vasc Surg 2006; 20: 120-9.

3. Koshiimichi M, Sugimoto K, Yanagida H, Fujita S, Miyazawa T, Sakata N, Okada M, Takemura T. Newly-identified symptoms of left renal vein entrapment syndrome mimicking orthostatic disturbance. World J Pediatr 2012; 8: 116-22.

4. Kurlinsky AK, Rooke TW. Nutcracker phenomenon and nutcracker syndrome. Mayo Clin Proc 2010; 85: 552-9.

5. Sheth S, Fishman EK. Imaging of the inferior Vena Cava with MDCT. AJR Am J Roentgenol 2007; 189: 1243-51.

6. Cuéllar I, Calàbria $\mathrm{H}$, Quiroga Gómez S, Boyé de la Presa R, Miranda A, Alvarez-Castells A. Nutcracker or left renal vein compression phenomenon: multidetector computed tomography findings and clinical significance. EurRadiol 2005; 15: 17 45-51.

7. Fong JK, Poh ACC, Tan AGS, Taneja R. Imaging findings and clinical features of abdominal vascular compression syndromes. AJR Am J Roentgenol 2014; 203 : 29-36.

8. Chen YM, Wang IK, Ng KK, Huang CC. Nutcracker syndrome: an overlooked cause of hematuria. Chang Gung Med J 2002; 25: 700-5.

9. Hanna HE, Santella RN, Zawada ET $\mathrm{Jr}$, Masterson TE. Nutcracker syndrome: an underdiagnosed cause for hematuria? S D J Med 1997; 50: 429-36.

10. Satyapal KS, Kaliden JM, Haffejee AA, Singh B, Robbs JV. Left renal vein variations. Surg Radiol Anat 1999; 21: 77-81.

11. Trigaux JP, Vandroogenbroek S, De Wispelaere JF, Lacrosse M, Jamart J. Congenital anomalies of the inferior vena cava and left renal vein with spiral CT. J Vasc Interv Radiol 1998; 9: 339-45.

12. Menard MT. Nutcracker syndrome: when should it be treated and how? Perspect Vasc Surg Endovasc Ther 2009; 21: 117-24. 